\title{
ИССЛЕДОВАНИЕ ЦИТОТОКСИЧНОСТИ НЕКОТОРЫХ КАРБОЦИКЛИЧЕСКИХ ЗАМЕЩЕННЫХ 1,3-ДИОКСОЛАНОВ
}

\section{Г.З. Раскильдина' Л.Х. Зарипова ${ }^{2}$ Ю.В. Вахитова², С.С. Злотский ${ }^{1}$}

${ }^{1}$ ФГБОУ ВО УГНТУ, 450064, Россия, г. Уфа, ул. Космонавтов, д. 1. ²ИБГ УФИЦ РАН, 450054, Россия, г. Уфа, Проспект Октября, д. 71, лит $1 \mathrm{E}$.

DOI: 10.19163/MedChemRussia2021-2021-411

E-mail: graskildina444@mail.ru

В продолжение ранее описанных работ [1,2], из этиленгликоля 1 и карбонильных соединений 2a, б были получены циклические ацетали 3а, б, которые использовались для синтеза карбоциклических замещенных 1,3-диоксоланов 4а, 6 (схема 1).

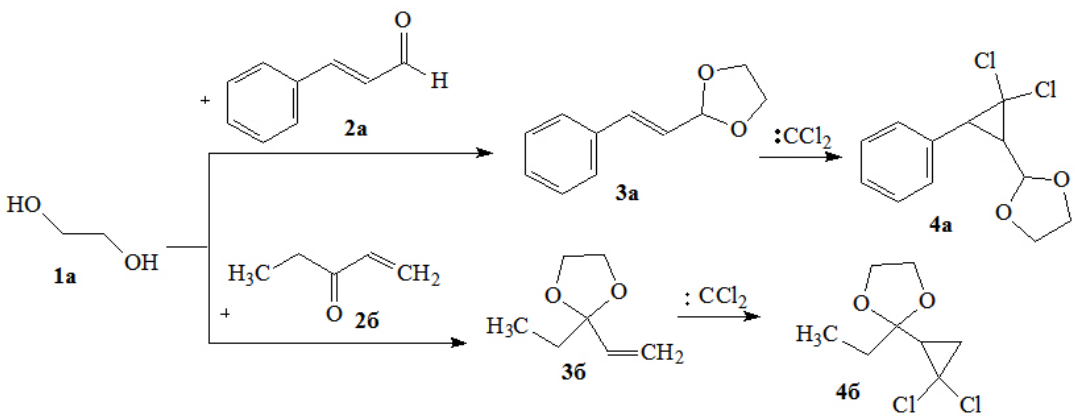

Схема 1.

Согласно результатам исследования влияния веществ 3а,б - 4а,6 на жизнеспособность клеток in vitro, цитотоксическую активность в отношении клеток линии HEK293, SH-SY5Y, Jurkat, HepG2, MCF-7 и A549 проявляют только соединения 4a (2-(2,2-дихлор-3-фенилциклопропил)-1,3-диоксолан) и 46 (2-(2,2-дихлорциклопропил)-2-этил-1,3-диоксолан), содержащие гемдихлорциклопропановый цикл.

Работа выполнена при финансовой поддержке гранта Президента РФ № МК-1689.2020.3 и в соответствии с планом госзадания ИБГУФИЦ РАН № AAAA-A21-121011990119-1.

\section{Литература}

[1] Г.З. Раскильдина, Е.А. Яковенко, Л.М. Мрясова, С.С. Злотский, Известия высших учебных заведений. Серия химия и химическая технология. 2019, 62, 1, 91-97.

[2] G.Z. Raskil'dina, U.Sh. Kuz'mina, Y.G. Borisova, S.S. Zlotskii, Pharm Chem. 2020, 54, 909-913. DOI: 10.1007/s11094-020-02295-8. 